\title{
More than a Historical Sidenote: The Nuclear Ambitions of the Shah of Iran
}

\author{
Jack Sargent ${ }^{1}$
}

\begin{abstract}
Scholarly work on nuclear proliferation tends to relegate the atomic aspirations of the Shah to the role of a framing device for the nuclear ambitions of the Islamic Republic of Iran. This approach is lacking, as it overlooks a large body of primary source material which portends to an alarming interest in, and potential movement towards nuclear weapons on the part of the Iranian ruler. This article will examine whether the Shah took any concrete steps towards developing nuclear weapons. In arguing that Mohammad Reza Pahlavi did so, two arguments are made. Firstly, that the Shah's nuclear energy programme, when completed, would have allowed for nuclear weapons to be developed. Secondly, there were multiple efforts by the Shah to procure weapon systems which are key in a functioning nuclear deterrent.
\end{abstract}

Keywords: Iran, nuclear weapons, Shah, Cold War.

\section{Introduction}

'Certainly, and sooner than is believed, but contrary to India, we have first thought of our people, and then of our technology.'2 This was the response of the Shah when questioned about the possibility of Iran obtaining a nuclear weapon following India's 1974 nuclear test. While it was immediately walked back, this slip alluded to atomic ambitions that would fit comfortably within the broader aims of Mohammad Reza Pahlavi, who sought to dominate the Gulf, and assert regional influence. The validity of his response is buttressed by a number of high-ranking Iranian officials. Asadollah Alam, a key confident of the Iranian monarch believed that his 'great vision for the future of this country ...

\footnotetext{
1 Jack Sargent is a postgraduate History and International Relations student at the London School of Economics and Political Science.

2 US Embassy Paris Cable 15445 to Department of State, 25 June 1974, National Security Archives, EBB no. 268 , doc. $1 \mathrm{~B}$.
} 
probably included [the] manufacturing of a nuclear deterrent. ${ }^{3}$ The head of the Atomic Energy Organisation of Iran (AEOI), Akbar Etemad, believed that 'if the shah had remained in power he would have developed nuclear weapons because now Pakistan, India and Israel all have them.' 4 Hassan Toufanian, the Iranian Vice Minister of War, followed similar lines. He felt that while a nuclear weapon was not pursued now, 't[h]at did not mean we would not be interested in another decade. ${ }^{5}$ The Shah's closest aides all believed in nuclearisation at some point in the future. This raises a startling question; did the Pahlavi dynasty take any concrete steps towards procuring nuclear weapons? This is the question this paper seeks to address. In doing so, this paper is divided into two parts; first, an exploration of the Shah's vast civil nuclear programme, which upon completion could have provided the ability to produce nuclear weapons. Secondly, three alarming arms purchases that strongly relate to nuclear ambitions are also discussed. These concern efforts to procure nuclear-capable short-range ballistic missiles (the 'Lance', 'SCUD' and project 'Flower') and the intriguing possibility that the Shah sought to purchase submarines capable of carrying nuclear ballistic missiles.

\section{The Nuclear Energy Programme}

Iran's nuclear energy programme could support nuclear weapons development. This was driven by the expanding scientific base of Iran, access to fissile material as well as the necessary information, and the processes of nuclear enrichment which the nuclear programme provided. The Shah announced his nuclear energy ambitions in March 1974, stating that ' $[\mathrm{w}] \mathrm{e}$ shall, as fast as we can, enter the age of using the atom and other sources of energy in order to save oil for production of chemical and petro-chemical products. ${ }^{6}$ This programme went through three phases, 'a first, experimental stage, with the support of the [U.S.] and [U.K.]...(1957-1973)...a period of significant expansion...(197376)...and finally, a relative lull in most nuclear activities (1977-78). ${ }^{7}$ The Shah's aim was to generate '...23,000 [Megawatt energy] of electricity with nuclear plants. ${ }^{8}$ Context

\footnotetext{
3 Asadollah Alam, The Shah and I: The Confidential Diary of Iran'Royal Court, ed. Alinaghi Alikhani, (New York, 1991), entry 8 April 1976, p. 478.

411 September 2008, 'The Shah's plan was to build bombs', The New Statesman.

51 April 1986, 'Documents Detail Israeli Missile Deal with the Shah', The New York Times.

${ }^{6}$ Gholam Reza Afkhami, Life and Times of the Shah, (California, 2008), p. 346.

${ }^{7}$ Michelle Gaietta, The Trajectory of Iran's Nuclear Program, p. 5.

${ }^{8}$ Ibid. p. 10.
} 
demonstrates the scale: '23,000 MWe is about the entire amount of nuclear energy generated at present in Russia. ${ }^{, 9}$

Iran's scientific base began with scientists receiving their education abroad, with the sending of 'some 300 students to West Germany, the United States, France and Britain for nuclear training... ${ }^{, 10}$ There were also large numbers of foreign advisors from India, France, West Germany and the US. This 'growth...stimulated the development of indigenous training and research facilities in various fields related to nuclear energy. ${ }^{11}$ This culminated in the 'AEOI ... employ[ing] more than 4,500 scientists.' 12 The AEOI also expanded its scientific base through hiring a number of notable consultants, such as Argentinian Naval Admiral Oscar Armando Quihillalt who 'served for fifteen years as head of the Argentinian nuclear program[me]. ${ }^{13}$

The Iranian scientific base benefitted from the massive military and nuclear energy programmes undertaken. Iran grappled with developing technical competence across a wide range of modern weapon systems. The Imperial Iranian Air Force (IIAF) in particular would have served to inculcate multiple generations of technicians, who could then translate their experiences dealing with advanced, precision equipment to nuclear technology. The Shah also sought co-production deals with the US to manufacture advanced weapon systems. Most obviously, the sheer scale of the Iranian nuclear energy programme would require significant numbers of nuclear technicians who could easily apply their knowledge to nuclear weapons.

With a viable scientific base, the next key stage is access to fissile material. Iran's primary source of fissile material would be its civilian programme. US intelligence analysis reported that 'the annual plutonium production from the planned 23,000 MW Iranian nuclear power program[me] will be equivalent to $600-700$ warheads. ${ }^{14}$ Similarly, U.S. congressional research indicated that 'the Iranians could build a minimum of 200 Hiroshima bombs a year.' ${ }^{15}$ These reports were predicated on Iran being able to reprocess spent nuclear fuel into fissile material. The prospect of Iran having complete control over

\footnotetext{
${ }^{9}$ Gaietta, The Trajectory of Iran's Nuclear Program, p. 10.

10 J Boureston \& CD Ferguson , 'Schooling Iran's Atomic Squad', Bulletin of Atomic Scientists, 60:3 (May/June 2004), p. 32.

${ }^{11}$ Ibid.

12 J Boureston \& CD Ferguson, 'Schooling Iran's Atomic Squad', p. 32.

${ }^{13}$ Quester, 'The Shah and the Bomb', p. 22.

1429 December 2010 'The Shah's Atomic Dreams', Foreign Policy.

1510 September 1974, U.S. Congress, Ninety-Third Congress, Second Session, Joint Committee on Atomic Energy, Subcommittee on Military Applications, 'Proliferation of Nuclear Weapons', (Washington, DC: US Government Printing Office, 1974), p. 30-31.
} 
the nuclear fuel cycle was the subject of protracted U.S.-Iran negotiations from 1974 to 1976. These 'ultimately failed to produce an agreement.' 16

There were two reasons for their failure; Iran could simply turn to European nuclear technology exporters like France and West Germany who would be ready to enter a deal with them without preconditions. West Germany had previously concluded a deal with Brazil that involved exporting spent fuel reprocessing technology. Secondly, ' $[\mathrm{t}] \mathrm{he}$ Iranians were simply unwilling to forgo the option of national reprocessing facilities', with Etemad stating bluntly that 'Iran considers reprocessing an important 'downstream' activity, and for obvious security of supply and economic reasons...intends to have it performed in...Iran.' ${ }^{17}$ Etemad and the AEOI 'understood that it was their patriotic duty to develop the scientific knowhow for a nuclear weapons program[me]. ${ }^{18}$

In support of this, 'Etemad quietly approved budget allocations for dual use projects, such as uranium enrichment... ${ }^{19}$ Iran would establish multiple streams for the procurement of uranium. As part of the dealings with France and West Germany, Iran would receive uranium from the European Gaseous Diffusion Uranium Enrichment Consortium (EURODIF). The AEOI also sought nuclear fuel from various African states, ${ }^{20}$ and concluded a 'secret agreement with South Africa in October 1975 to purchase enriched uranium. ${ }^{21}$ Seeing American efforts to impose restrictions as untenable, the Shah concluded a deal with France and West Germany. Iran 'finalised an $\$ 8$ billion deal to build a total of eight nuclear reactors ${ }^{22}$ with France, and with West Germany to provide nuclear fuel reprocessing technology, which Kissinger fumed 'will still look like Brazil', ${ }^{23}$ referencing the controversial West German deal to supply Brazil with the full nuclear cycle.

\section{Alarming Arms Purchases}

The MGM-52 Lance was an American tactical ballistic missile, with a nuclear (optionally conventional) warhead and a range of up to $130 \mathrm{~km}$. It was principally a nuclear weapon;

\footnotetext{
${ }^{16}$ Alvandi, Nixon, Kissinger and the Shah, p. 130.

${ }^{17}$ US Embassy in Tehran 7485 to US Department of State, 23 July 1976, Telegram, EBB 268, NSA-GWU.

${ }^{18}$ Akbar Etemad in an interview with Gholam Reza Afkhami, London, September 5, 1995, Tape C1-3A, FISOHC.

19 Ibid.

${ }^{20}$ CIA Memorandum, "Israel and Iran in Sub-Saharan Africa," June 19, 1975, CREST.

2112 October, 1975, 'S. Africa Set to Sell Iran Uranium Ore', Washington Post.

22 Scowcroft to Ford, August 9, 1976, National Security Archives, Trip Briefing Books and Cables for HAK, Box 40, GRFL.

${ }^{23}$ Memorandum of Conversation, 2 July 1976, EBB 268, NSA-GWU.
} 
its conventional variant was only effective with a cluster munition warhead, owing to inaccuracy. It was mobile, being deployed via a transporter-erector launcher. ${ }^{24}$ In 1975 , 'ARMISH/MAAG was...requested to provide information on the price and availability of 3 to 6 battalions of LANCE. ${ }^{25}$ This was rejected. The Shah then instructed Toufanian to 'ask...the USSR to provide surface-to-surface (probably SCUD) missiles.' However, '[t]he Soviets reportedly turned him down.' ${ }^{26}$ The SCUD was a Soviet analog to the Lance, with twice the range. As U.S. government analysis aptly notes, 'the Shah's willingness to approach the USSR...suggests he's willing to pay a considerable political price' for such a system. ${ }^{27}$ The attempted purchase of the Lance and SCUD missiles is an often-overlooked attempt at purchasing a key component of a viable nuclear deterrent.

The Shah's stated need for the Lance or SCUD was spelled out in a meeting with U.S. Defence Intelligence Agency (DIA) General Wilson, where 'he emphasised his need for a weapons system capable of neutralising Iraqi SAM (Surface-to-Air Missiles) sites without risking the loss of large numbers of aircraft. ${ }^{28}$

This reasoning is specious at best. At the time, the aerial doctrine of Suppression of Enemy Air Defences (SEAD) had been developed in the Vietnam War, and was effective against a vast and intricate Soviet-designed air defence network. SEAD involved aircraft such as the F-4 Phantom (a key IIAF plane), which in its SEAD variant was held to be 'the king of SEAD from Vietnam to the Gulf.' ${ }^{29}$ Consequently, Iran could not have needed the above mentioned missiles for SEAD, nor could they be considered adequate for the role in the first place.

U.S. memos warned that "[a]lthough we would be selling the conventional warhead, many Congressmen (and the press) would relate the sale to Iran's nuclear development program[me]. ${ }^{30}$ The Lance's range, and the technical issues relating to warhead miniaturisation would have prevented their immediate nuclear use. It is likely that the Shah desired them not for immediate use, but to reduce the technical barriers to

\footnotetext{
${ }^{24}$ Missile Defense Project, 3 March 2017, 'MGM-52 Lance' Center for Strategic and International Studies, last modified June 15, 2018, https://missilethreat.csis.org/missile/lance/.

${ }^{25}$ Department of State, 1 May 1975, 'Department of State Briefing Paper for U.S Visit of Shah of Iran: Military Supply-Lance Missile, Department of State, GALE | CK2349001892, p. 1.

${ }^{26}$ Robert Oakley, 10 December 1976, 'In a memorandum to National Security Adviser Brent Scowcroft, National Security Council (NSC) staff member Robert Oakley discusses present U.S.-Iranian relations and a recent agreement between Iran and the Soviet Union for the Iranian purchase of arms' National Security Council, GALE | CK2349589990, p. 2.

${ }^{27}$ Ibid.

${ }^{28}$ Robert Oakley, 10 December 1976, 'Robert Oakley discusses present U.S.-Iranian relations, p. 2.

29 'Dealing with Air Defences', Air Force Magazine, November 1999, p. 26.

${ }^{30}$ Department of State, Briefing Paper for U.S. Visit of Shah of Iran: Military supply - Lance Missile, p. 2.
} 
deploying and maintaining nuclear capable missiles. The Shah also 'expressed a strong interest in the manufacture of certain items of U.S. military hardware in Iran...specifically...the 2.75 ' air-to-ground rocket, the AGM-65A...air-to-ground missile, the TOW and DRAGON anti-tank missile systems. ${ }^{31}$ While these were missiles which served vastly different purposes to the SCUD and the Lance, being able to manufacture them would lay the foundations for a missile programme which could — prospectively — support the independent production of Lance/SCUD level missiles.

While the Lance and SCUD affair showcased a desire for short-range ballistic missiles, the Joint Iranian-Israeli 'Flower' project demonstrated the importance the Shah placed on such a capability. This was a billion-dollar agreement with Israel where Iran would finance the programme, and Israel would produce the missile. The transaction was greatly assisted by large shipments of Iranian oil, being one of many arms-for-oil agreements between the two nations. Most damningly, the two went to great lengths to hide their efforts from the U.S., with Israel seeking to use only domestic parts to prevent a U.S. export veto, and Iran not informing the U.S. whatsoever. Both sides were aware of the significance of this, with Moshe Dayan reportedly stating that 'at some stage, the problem will have to be raised with the Americans' and that he would seek to discuss this with the Shah directly. ${ }^{32}$

The missile itself was significant, having a range of $480 \mathrm{~km}$, and carrying a warhead weighing $750 \mathrm{~kg}$. This, in the words of Dayan, meant that 'the missile...can be regarded as a missile with a nuclear head, because with a head of $750 \mathrm{KG}$ it can be a double-purpose one.' 33 The missile also reached a late stage of development, with a successful test being carried out in Israel, which Toufanian observed, gushing that 'it was a beautiful...fully developed missile. ${ }^{34}$ Investigation into the subject reveals that following this, missiles were 'to be shipped through a Swiss company to central Iran for assembly and testing. ${ }^{35}$ While technical problems such as dealing with the missile relying on 'American-made... [equipment]...that Israel was forbidden to [export]' ${ }^{36}$ were still to

\footnotetext{
${ }^{31}$ US Department of State, 1 May 1975, 'military policy-co-production in Iran', Department Of State, GALE | CK2349001887, p. 1.

32 'Documents Detail Israeli Missile Deal with the Shah', p. 2.

${ }^{33}$ Ibid, $\mathrm{p} 1$.

34 'Documents Detail Israeli Missile Deal with the Shah', p. 1.

${ }^{35}$ Ibid.

36 'Documents Detail Israeli Missile Deal with the Shah', p. 1.
} 
be overcome, barring the Iranian revolution, the Shah would have come into possession of a short-range ballistic missile capability.

It can be argued that the efforts to acquire the Lance, SCUD and 'Flower' missiles was an attempt by the Shah to develop an initial operating capability of short-range ballistic missiles, and the technical ability to operate, and perhaps even manufacture, his own in the future. These could have served as a readily available short-range delivery system for nuclear weapons, and thus represented a concrete step towards developing them. The SCUD, and to a lesser extent the Lance, could target key Iraqi installations from within Iran. The 'Flower' project missile could carry more, farther. Having ready access to nuclear-capable missiles would prevent being denied access to them later, should the superpowers refuse to tolerate a nuclear Iran. Thus the lengths the Shah went to in order to acquire short-range ballistic missiles, which his strategic situation did not immediately necessitate at the time, indicates that Mohammad Reza Pahlavi sought ballistic missiles to make nuclear weapons more feasible.

More evidence that the Shah sought to purchase key weapon systems for a nuclear deterrent is an alleged attempt to purchase nuclear submarines from France. Documentary sources surrounding this are scarce, with the primary basis for this being a telephone conference transcript of a conversation between U.S. Secretary of State Henry Kissinger, and Pierre Brousalette, the Secretary General of the Office of the Presidency of France. This exchange has not been dealt with whatsoever in scholarship. In this short exchange, Brousalette outlines that France has been 'under some pressure lately from Spain and Tehran...both would like us to buy in the future nuclear-powered submarines... [t]he people from Tehran have been hinting the U.S. might sell them in the future - the nuclear powered submarine. ${ }^{37}$

Odd choice of word aside, it seems that Brousalette was alleging that Tehran wanted to purchase nuclear submarines from a trusted nuclear energy partner (France had built multiple Iranian nuclear reactors), and that the U.S. was already considering selling them submarines. Kissinger was seemingly irate, stating '[i]ts inconceivable and there's no way a subordinate department can do this without me knowing about it. ${ }^{38}$ Adding to the bizarre nature of this, is the fact that at this moment France only operated nuclear-

\footnotetext{
37 Henry Kissinger and Pierre Brousalette, 8 January 1975, 'State Department Telephone Conference Transcript, Pierre Brousalette Secretary General of the Office of the President of France/Secretary of State Kissinger', Kissinger Telephone Conversations, 1969-1977 p 1.

${ }^{38}$ Ibid.
} 
powered ballistic missile submarines. France's first ballistic missile submarine, Le Redoutable was laid down in 1964 and commissioned in 1971. France's first nuclear attack submarine was launched in 1983, a full eight years following this exchange. While this could be another attempt by the Shah to 'co-finance' another major weapons system, this is dubious at best, given the intense secrecy which surrounds nuclear submarines. Further, this being a French ploy cannot be ruled out either.

Interestingly, during the Project 'Flower' talks, Admiral Habibollahi of Iran mentions to Admiral Barkai of Israel in July 1978 'the possibility of enhancing the Flower project so that the missiles could be launched from submarines. ${ }^{39}$ Habibollahi later explained that 'we were considering tactical, nonnuclear missiles for our submarines. ${ }^{40}$ However this must be framed by the fact that Iran's intended non-nuclear missile was not in any way limited from carrying a nuclear payload. While a nuclear submarine would be of little use in the Persian Gulf, a possible role for said submarine could be to provide a guaranteed second strike ability, taking advantage of Iran's access to the Indian Ocean. While this would certainly be strongly indicative of an attempt to develop a nuclear deterrent, the lack of further documentary sources limit its reliability.

\section{Conclusion}

The spectre of a nuclear Imperial Iran occurring but for the Iranian revolution, as forecast by the Shah's closest confidants, deserves much greater scholarly attention. The gap which this article has highlighted is symptomatic of issues within the broader literature on Iranian nuclear proliferation, where the atomic aspirations of the Shah are used only to frame those of his revolutionary successor. In pushing against this tendency, this paper has sought to engage with the prospect of whether the Shah had taken any steps towards procuring a nuclear deterrent. In doing so, this paper has advanced two arguments in support of the position that the Shah did indeed move towards nuclearisation. Firstly, that the scale of the Iranian nuclear energy programme would have allowed for Iran to manufacture nuclear weapons, largely unhindered. This was achieved through securing nuclear fuel supplies, forming a large scientific base, and a nuclear fuel processing chain, which would allow for the enrichment of uranium. Secondly, three arms purchases were examined, which indicate a strong desire on the part of the Shah to operate weapons

\footnotetext{
39 'Documents Detail Israeli Missile Deal with the Shah', p. 2.

40 Ibid.
} 
systems which would ultimately be of use in developing a nuclear deterrent. These were the Lance, the SCUD and the Project 'Flower' missiles. The article has also considered documentary evidence which points towards attempts to purchase nuclear submarines. Taken together, these display on the part of the Shah an interest in the ability to nuclearize, along with seeking arms purchases necessary to field a nuclear deterrent. 